\title{
Coastal Erosion Due to Seawater Intrusion into Groundwater Aquifers
}

\author{
Ramani Bai V*
}

Department of Civil Engineering, Faculty of Engineering, University of Nottingham Malaysia Campus, Jln Broga, Semenyih, Selangor, 43500 Malaysia

\begin{abstract}
Problem Statement: In general, the drinking water systems sourced from ground water (GW) contains chemicals at double the current maximum contaminant levels (MCL) of colloids. However, due to increasing demand of water, groundwater may be subjected to over-exploitation and the natural equilibrium is thus disturbed. A steady-state condition is established between seawater and freshwater in a coastal aquifer. This results in aggressive groundwater-surface water interaction, which may even reach the inland aquifer. Approach: The objectives of this research are to determine the level of contamination of groundwater by seawater intrusion and to identify its hazard. A flow model is created using the study area, Kanchong Darat in state of Selangor in West Malaysia in Visual MODFLOW environment. By a transient-state analysis the environmental impact due to groundwater pumping has been studied and the results of are obtained. Conclusion: The simulation results revealed that GW would get lower, and finally the interface between fresh and saltwater could gradually move inland if the abstraction of GW is continued and become over-exploited. In the model the drawdown (DD) at the top most aquifer (depth of $55 \mathrm{~m}$ ) has been found with a depression cone of radii around $3650 \mathrm{~m}$ after 1 day of pumping; the radii reached $7500 \mathrm{~m}$ with depth of DD $55.5 \mathrm{~m}$ after 10 days, while after 30 days of pumping; it reached about $10 \mathrm{~km}$ with DD 56.8m. These models are useful for better water resource management and to understand the coastal hazards into inland resources wherein $75 \%$ of the water resource is based on groundwater system.
\end{abstract}

Keywords: Groundwater quality, Groundwater pumping, seawater intrusion, coastal hazards and Water resource management.

\section{INTRODUCTION}

Groundwater $(\mathrm{GW})$ modeling is one of the most important topics in engineering and geosciences. It is too difficult to exactly model the hydraulics of interaction surface of groundwater and surface water. It is a powerful management tool which can serve multiple purposes such as providing a framework for organizing hydrologic data, quantifying the properties and behavior of the systems, and allowing quantitative prediction of the responses of those systems to externally applied stresses. It is very useful in the management of groundwater resources, observation of the groundwater flow in aquifer, predicting the geological structure due to the groundwater abstraction, protecting the groundwater sources from contamination and so all.

The codes most commonly used by hydro geological professionals are MODFLOW, MT3D, MT3DMS, RT3D, and BIOPLUME III. These codes provide numerical solutions to the partial differential equations describing ground water flow and the fate and transport of contaminants. In this paper, a transient-state analysis of groundwater pumping is being considered, by using the well-known threedimensional (3D) computer software package, Visual Modflow. It is to be proved that Visual Modflow is efficient in groundwater flow modeling and hence the ability to simulate

\footnotetext{
*Address correspondence to this author at the Department of Civil Engineering, Faculty of Engineering, University of Nottingham Malaysia Campus, Jln Broga, Semenyih, Selangor, 43500 Malaysia; Tel: +6 03 89248604; E-mail: vramanibai@gmail.com
}

the system to investigate seawater intrusion hazards.Su et al. (1998)[1] proposed a numerical model to study ground deformation caused by lowering of the water table from a single pumping well. The model used the finite element method to study the problem. In the model, the Dupuit assumption was not used due to errors that might be introduced by ignoring the seepage face and vertical flow component. Instead, a two-step iteration procedure was used to determine the actual flow paths. Field testing was performed to verify the numerical calculations. Ground deformations were measured under different pumping rates. The field measurements of the ground deformation matched well with the calculated values.

Thangarajan et al. (1999)[2] attempted a groundwater modeling study in Upper Thamalakane River valley, Okavango Delta, Botswana (southern Africa). VisualModflow program and processor developed by McDonald and Harbaugh (2003)[3] and Guiger and Franz (1996)[4] was used for graphical data input, analysis and presentation of the output data. The aquifer system in the valley was conceptualized as five-layer system by making used of available data and an artificial aquitard was placed in the system for the modeling purpose. The hydrodynamic behavior was studied under two prediction scenarios to evolve appropriate management decisions for locating the well field in the upper aquifer by making used of induced river infiltration during the flood season.

Gogu et al. (2001)[5] designed a hydrogeological geographic information system (GIS) database that offers facili- 

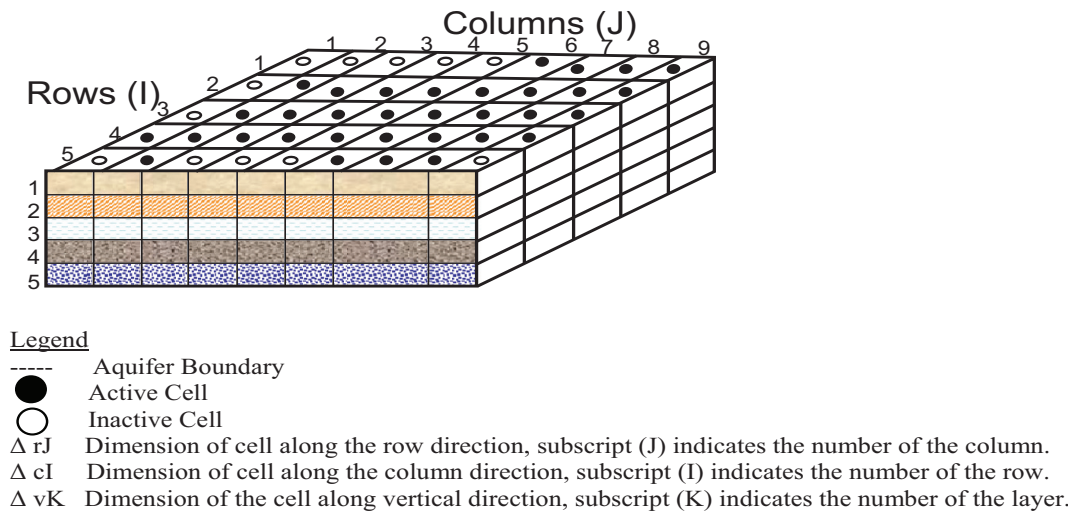

Fig. (1). Discretization of groundwater aquifer system.

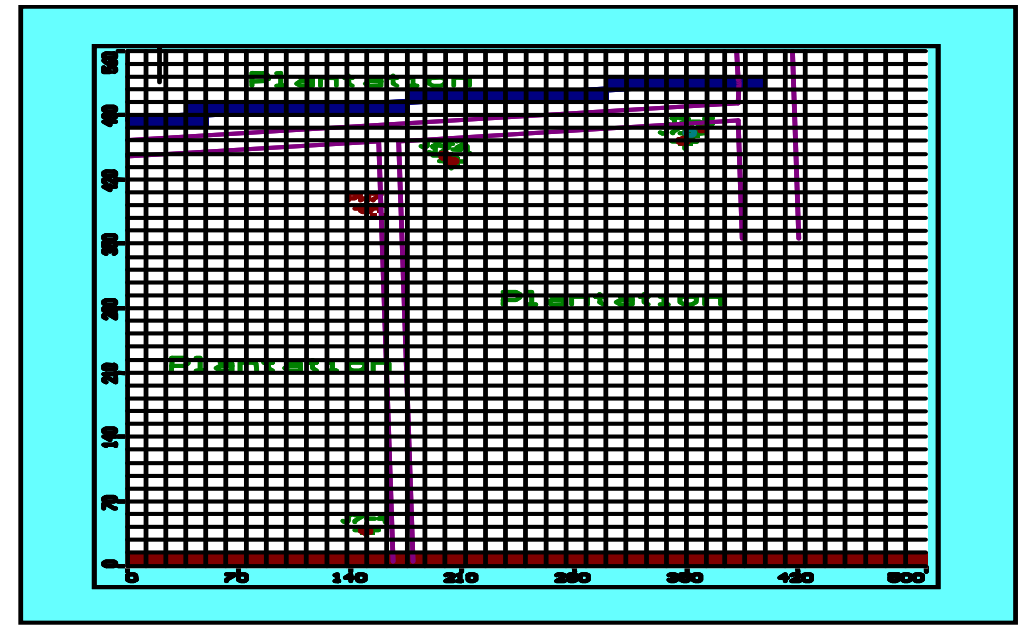

Fig. (2). Model Domains with the assigned boundary condition.

ties for groundwater-vulnerability analysis and hydrogeological conditions in regions of Belgium. Data from five river basins, chosen for their contrasting hydrogeological characteristics, have been included in the database, and a set of applications that have been developed allow further advances. The hydrogeological GIS database described in this paper offers capabilities for hydrogeological modeling as well as other hydrogeological studies, such as data verification and validation, automatic data treatment, a global view of the hydrogeological data, generated maps of aquifer parameters, made correlations between groundwater hydrochemical parameters, aquifer depth, lithology and land use, and performed aquifer vulnerability studies using the existing spatial database.

\section{MATERIALS AND METHODS}

The three-dimensional movement of groundwater (GW) of constant density through porous earth material may be described by the partial-differential equation (Rushton and Redshaw 1979) as follows and is shown in Fig. (1),

$$
\frac{\partial}{\partial x}\left(K_{x x} \frac{\partial h}{\partial x}\right)+\frac{\partial}{\partial y}\left(K_{y y} \frac{\partial h}{\partial y}\right)+\frac{\partial}{\partial z}\left(K_{z z} \frac{\partial h}{\partial z}\right)-W=S_{S} \frac{\partial h}{\partial t}
$$

Where, Kxx, Kyy, and Kzz are values of hydraulic conductivity along the $\mathrm{x}, \mathrm{y}$, and $\mathrm{z}$ coordinate axes, which are assumed to be parallel to the major axes of hydraulic conductivity $\left(\mathrm{LT}^{-1}\right) ; \mathrm{h}$ is the potentiometric head $(\mathrm{L}) ; \mathrm{W}$ is a volumetric flux per unit volume and represents sources and/or sinks of water $\left(\mathrm{T}^{-1}\right)$; Ss is the specific storage of the porous material $\left(\mathrm{L}^{-1}\right)$; and $\mathrm{t}$ is time $(\mathrm{T})$. Equation (1), together with specification of flow and/or head conditions at the boundaries of an aquifer system and specification of initial-head conditions, constitutes a mathematical representation of a ground-water flow system.

Fig. (1) shows a spatial discretization of an aquifer system with a mesh of blocks called cells, the locations of which are described in terms of rows, columns, and layers. Within each cell there is a point called a "node" at which head is to be calculated.

GW flow model: A flow model is created using the study area, Kanchong Darat in Visual MODFLOW environment. The base map that was using to create the model was in .DXF form. It was drawn in real size by using the AutoCAD and imported as background map. Then the number of columns, rows and layers of the model domain was specified, that were 40 columns, 40 rows and 6 layers and the model is shown in Fig. (2). Table 1 shows the properties assigned such as hydraulic conductivity for each of the layers in direction $\mathrm{x}, \mathrm{y}, \mathrm{z}$; specific storage, specific yield and effective porosity. They are collected from DID publication of Malaysia (Jabatan Penyasiatan Kajibumi Malaysia, 1998) [6]. The horizontal hydraulic conductivity in direction y was automatically filled when the value of hydraulic con ductivity in direction $\mathrm{x}$ was entered, since Visual MODFLOW assumes horizontal isotropy. 
Table 1. Properties of the Aquifer Adopted in the Model

\begin{tabular}{|c|c|c|c|c|c|c|c|c|}
\hline \multirow[t]{2}{*}{ Layer No. } & \multirow[t]{2}{*}{ Depth (m) } & \multicolumn{2}{|c|}{$\begin{array}{c}\text { Horizontal Hydraulic } \\
\text { Conductivity }\end{array}$} & \multirow{2}{*}{$\begin{array}{c}\text { Vertical Hydraulic } \\
\text { Conductivity } \\
\text { in } \mathbf{z}(\mathrm{Kz})\end{array}$} & \multirow{2}{*}{$\begin{array}{c}\text { Specific } \\
\text { Storage, Ss }\end{array}$} & \multirow{2}{*}{$\begin{array}{l}\text { Specific } \\
\text { Yield, Sy }\end{array}$} & \multirow{2}{*}{$\begin{array}{l}\text { Effective } \\
\text { Porosity }\end{array}$} & \multirow[t]{2}{*}{ Soil Description } \\
\hline & & in $x(K x)$ & in $\mathbf{y}(\mathbf{K y})$ & & & & & \\
\hline 1 & 4 & $1.00 \mathrm{E}^{-04}$ & $1.00 \mathrm{E}^{-04}$ & $1.00 \mathrm{E}^{-05}$ & 0.3 & 0.35 & 0.35 & Peat, peaty soil \\
\hline 2 & 22 & $5.47 \mathrm{E}^{-06}$ & $5.47 \mathrm{E}^{-06}$ & $7.20 \mathrm{E}^{-09}$ & 0.01 & 0.7 & 0.7 & Silty clay and silty sand \\
\hline 3 & 56.5 & $1.61 \mathrm{E}^{-04}$ & $1.61 \mathrm{E}^{-04}$ & $2.47 \mathrm{E}^{-08}$ & 0.11 & 0.4 & 0.4 & $\begin{array}{l}\text { Silty sand and silty clay } \\
\text { with gravel }\end{array}$ \\
\hline 4 & 63 & $6.00 \mathrm{E}^{-05}$ & $6.00 \mathrm{E}^{-05}$ & $3.00 \mathrm{E}^{-06}$ & 0.01 & 0.4 & 0.4 & Silty clay and silty sand \\
\hline 5 & 83 & $1.08 \mathrm{E}^{-03}$ & $1.08 \mathrm{E}^{-03}$ & $5.93 \mathrm{E}^{-07}$ & 0.18 & 0.4 & 0.4 & $\begin{array}{l}\text { Silty sand and gravel, } \\
\text { sandy clay }\end{array}$ \\
\hline 6 & 120 & $8.00 \mathrm{E}^{-04}$ & $8.00 \mathrm{E}^{-04}$ & $3.20 \mathrm{E}^{-05}$ & 0.2 & 0.4 & 0.4 & Silty sand with gravel \\
\hline
\end{tabular}

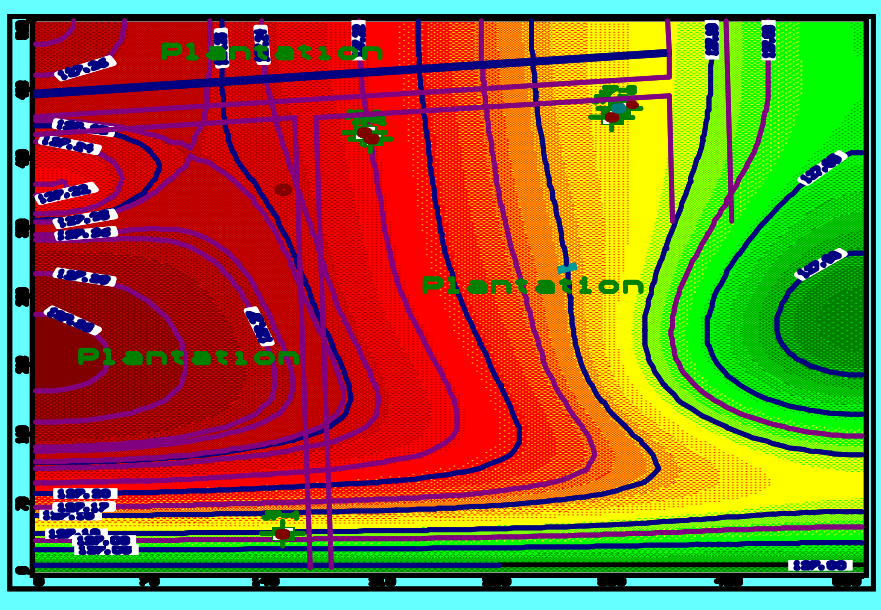

Fig. (3). Simulated head Equipotential.

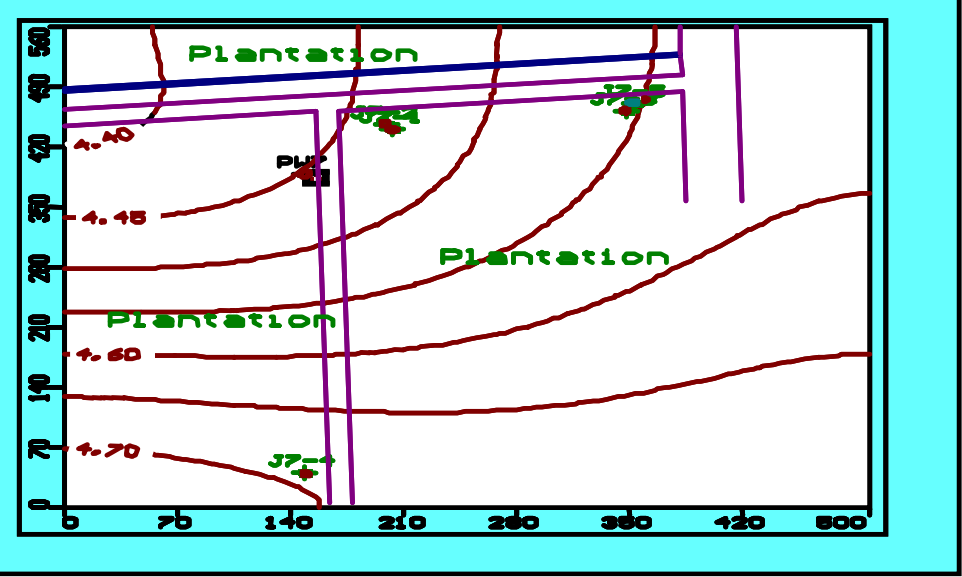

Fig. (4). Drawdown contour map of the second layer.

The boundary conditions which were going to be assigned are constant head, river, recharge and evapotranspiration. The location of the study area was about $8.5 \mathrm{~km}$ to the north of the seacoast. Thus, it was taken as a constant head of the bottom part (southern) of the model. The Pan Evaporation can be assumed empirically as " 0.8 x Potential Evapotranspiration by Penman Method". Further in line with the existing document, namely "DID, Evaporation in Peninsular Malaysia, Water Resource Publication No. 5, 1994", Actual Evaporation is assumed empirically as "0.8 x Pan Evaporation" in Malaysia. Hence, Actual Evaporation (Es- timated Evapotranspiration) can be estimated as $0.64 \mathrm{x}$ Potential Evaporation. Thus, the Actual Evaporation was taken as the assigning value of evapotranspiration in this model. Results of head equipotential of the study area indicate that the highest heads are found on the western and northern side of the study area. The heads decrease slowly towards the eastern and southern side of the study area, which is a general reflection of the topography. The groundwater flow direction is towards the eastern and southern side. Fig. (3) shows the head equipotential of the study area, while Fig. (47) shows the head equipotential contour map for each layer 


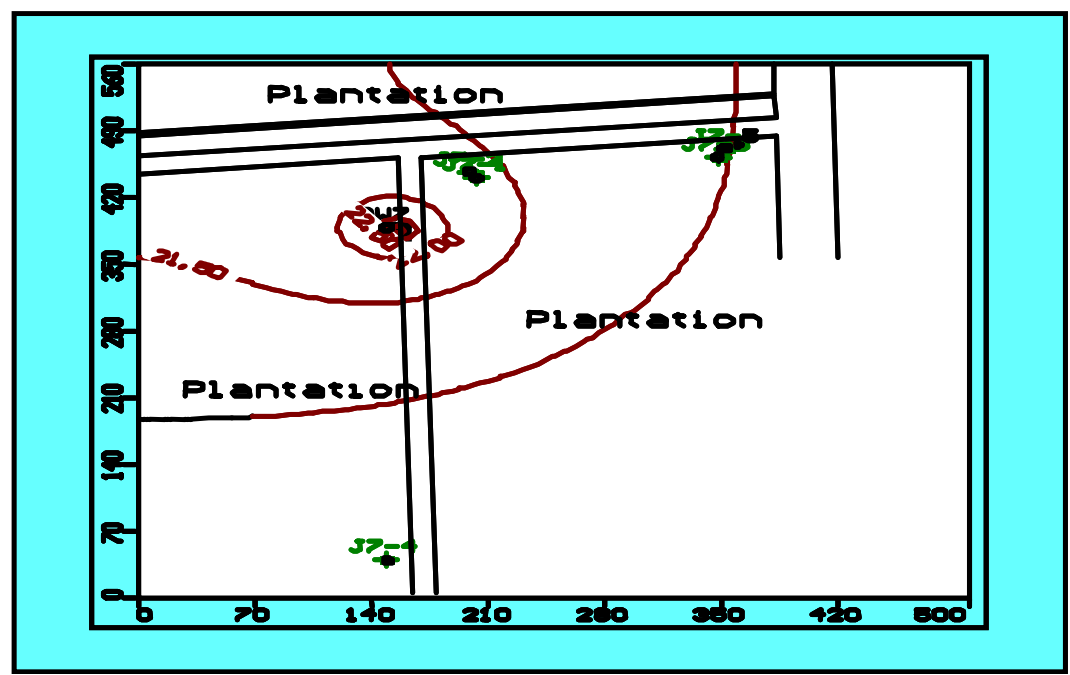

Fig. (5). Drawdown contour map of the third layer.

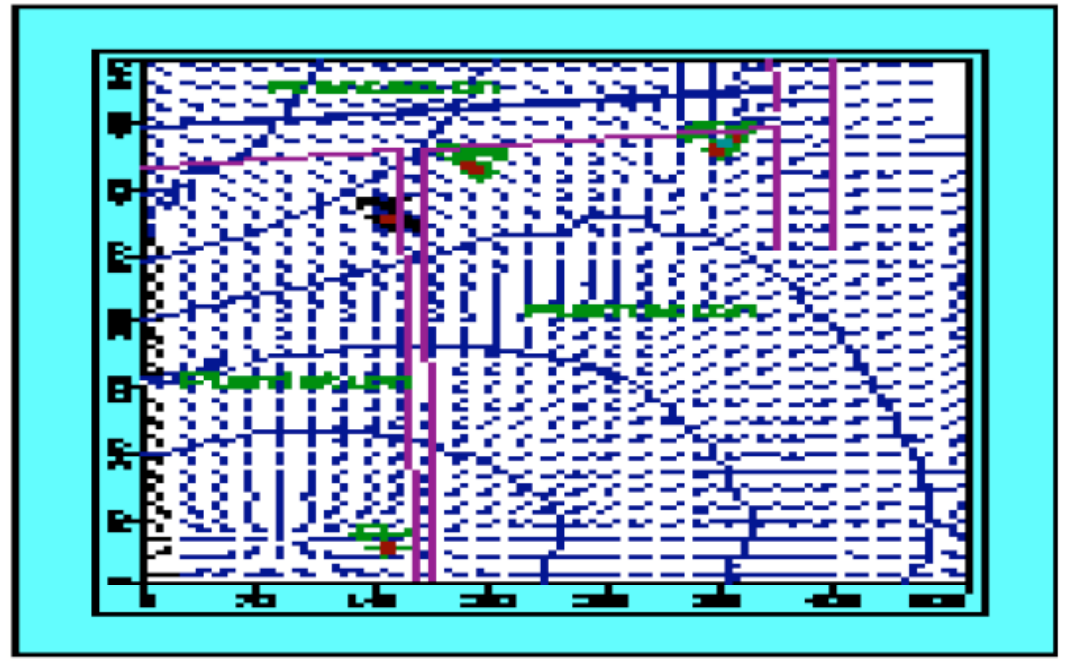

Fig. (6). Head equipotential contour map of the third layer.

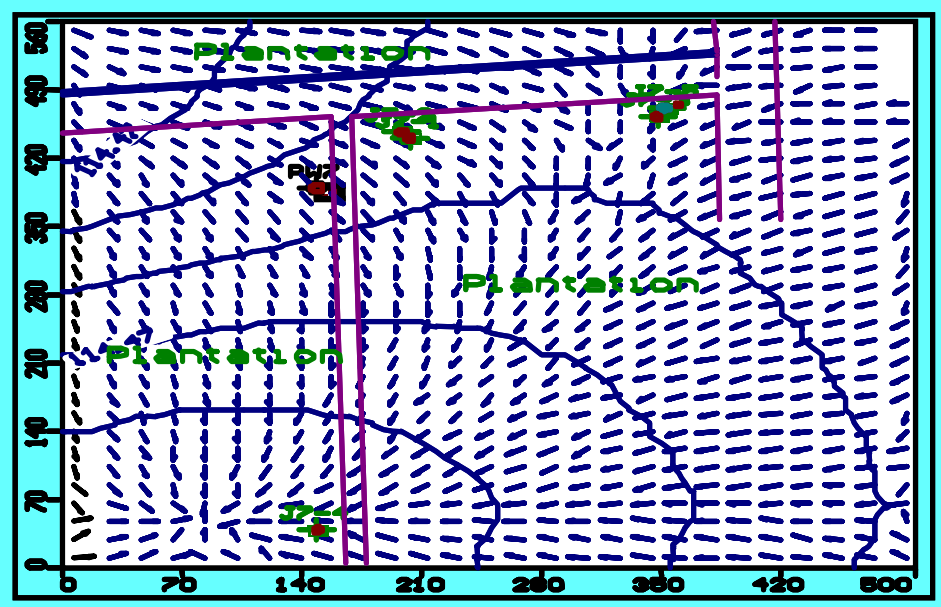

Fig. (7). Head equipotential contour map of the fifth layer.

of the study area together with the directions of the groundwater flow. Fig. (6 and 7) shows the direction of flow of water towards the well indicating the flow inland of the coasts.

\section{RESULTS AND DISCUSSION}

The simulation results of head equipotential lines are plottded in Fig. $(\mathbf{6}, \mathbf{7})$. The boundary condition in the southern part of the study area was defined as a constant head 


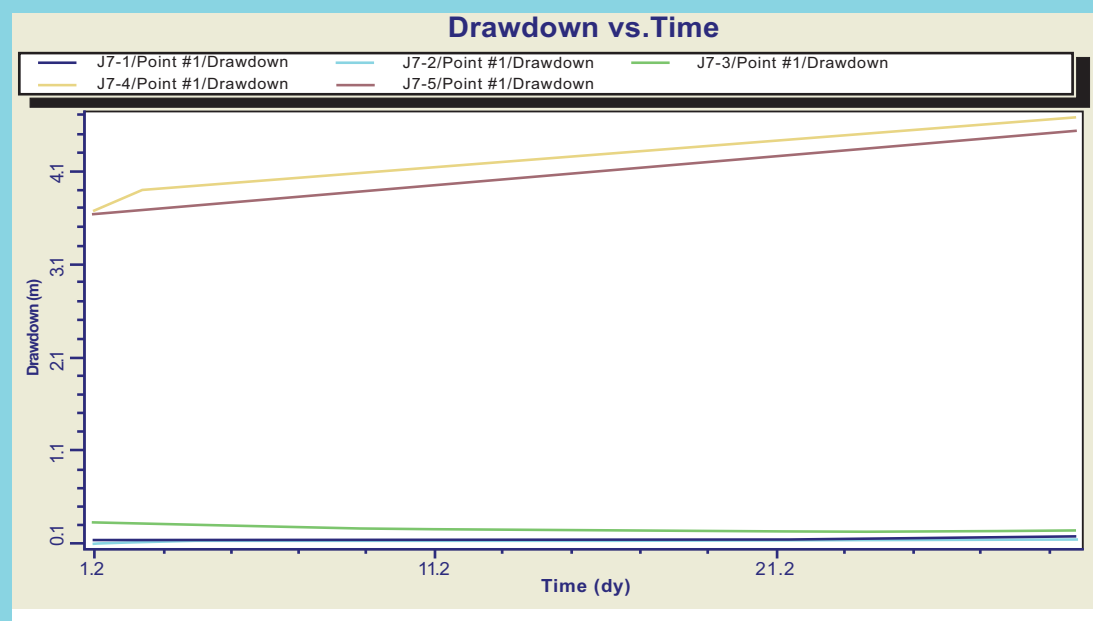

Fig. (8). Drawdown Curve of observation wells.

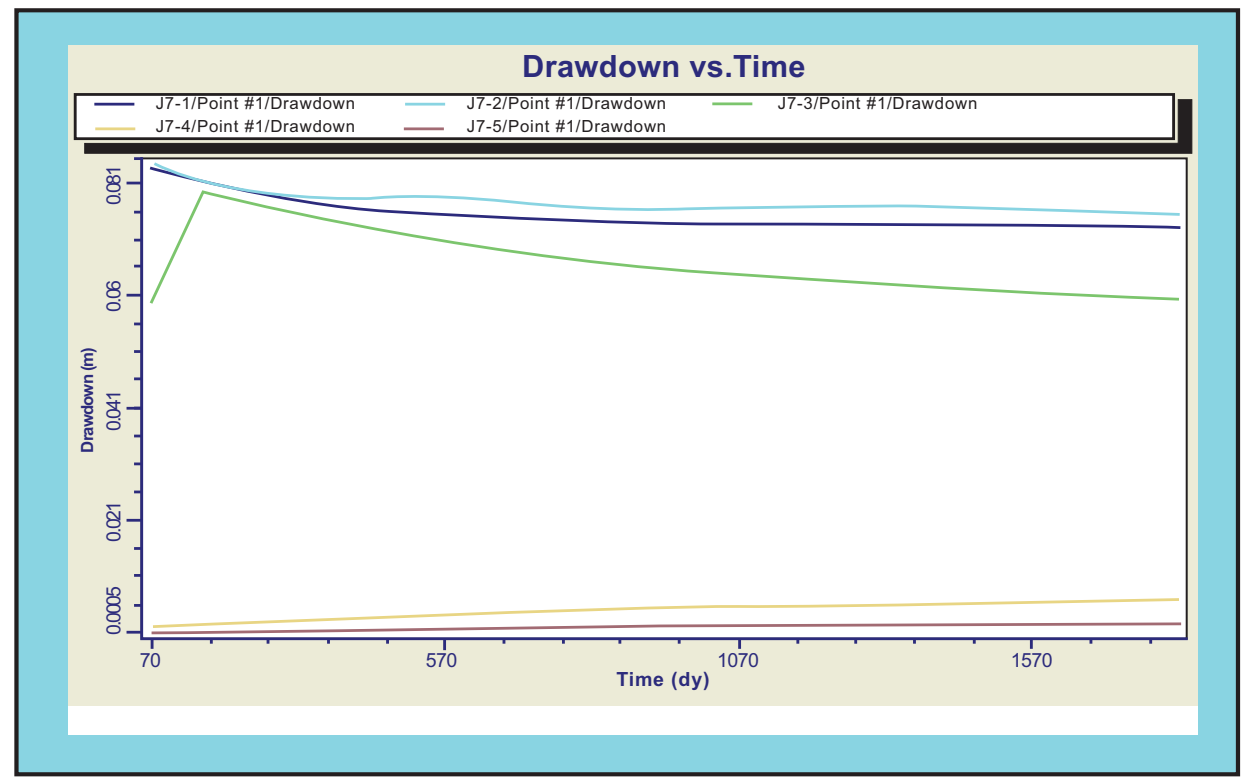

Fig. (9). Simulation results: Drawdown Curve after the artificial recharge.

condition, where the coastal is located $8.5 \mathrm{~km}$ away from the study area. It is found that there has some small degree of net recharge to the aquifer from the southern part of the study area, which is about $60 \mathrm{~mm} / \mathrm{year}$. Thus, seawater intrusion will be the potential problem to this area if the over- pumping of groundwater is carried out form the aquifer. The change of groundwater quality due to saline intrusion by over-exploitation of groundwater is expected in Kanchong Darat. Groundwater flow together with the environmental effects is not just affected by local problems but also by the neighboring areas. There are two piezometers for observation of shallow and deep aquifer which can help in adding the accuracy of groundwater sampling results.

Environmental Impact due to groundwater pumping: Results of Transient-state Analysis are plotted in Fig. $(\mathbf{8}, 9)$ and the contour maps are plotted for $\mathrm{K} \& \mathrm{~S}$. It is observed that in short-term period (1 day) the recharge of groundwater in the study area is poor or not quite obvious. The simulation re- sults revealed that the drawdown (DD) in the top most aquifer (depth of $55 \mathrm{~m}$ )) resulted a depression cone with the radii around $3650 \mathrm{~m}$ as in Fig. (9). Some places, after 1 day of pumping; the radii reached $7500 \mathrm{~m}$ with depth of DD $55.5 \mathrm{~m}$ after 10 days, while after 30 days of pumping, it reached about $10 \mathrm{~km}$ with DD $56.8 \mathrm{~m}$. From Fig. (9), it is understood that the aquifer in the study area is able to yield a high quantity of water, with small value of drawdown with artificial recharge of groundwater.

Environmental Hazards due to Groundwater exploitation: In short-term period ( 1 day) the recharge of groundwater in the study area is poor or not quite obvious. The simulation results revealed that the drawdown (DD) in the top most aquifer (depth of $55 \mathrm{~m}$ )) resulted a depression cone with the radii around $3650 \mathrm{~m}$. From Fig. (9), after 1 day of pumping; the radii reached $7500 \mathrm{~m}$ with depth of DD $55.5 \mathrm{~m}$ after 10 days, while after 30 days of pumping; it reached about $10 \mathrm{~km}$ with DD $56.8 \mathrm{~m}$. From Fig. (9), it is understood 
that the aquifer in the study area is able to yield a high quantity of water, with small value of drawdown with artificial recharge of groundwater.

\section{CONCLUSION}

A nonlinear three-dimensional numerical model technology is developed to simulate the effect of $\mathrm{GW}$ pumping along west coasts of Peninsular Malaysia in aqueous environment. If the abstraction of $\mathrm{GW}$ is continued and become over-exploited, GW would get lower, and finally the interface between fresh and saltwater could gradually move inland. Not only the movement of the interface, but is baneful influence on the crops predicted and affecting the groundwater quality. Furthermore, the data analysis made possible by use of nonlinear parameter estimation methodologies allows you to make judgments about the degree of uncertainty associated with model predictions, and to make decisions regarding appropriate levels of model complexity. The calibrated model can be used to predict future groundwater heads in the confined aquifer in the year 2020 with an estimated increase in pumping as result of presence of colloidal and noncolloidal particles present in groundwater. These modes are useful for better water resource management and understand the coastal hazards of the basin wherein $75 \%$ of the water resource is based on groundwater systems.

\section{CONFLICT OF INTEREST}

The author confirms that this article content has no conflicts of interest.

\section{ACKNOWLEDGEMENT}

Declared none.

\section{REFERNCES}

[1] Su MB, Su CL, Chang CJ, Chen YJ. A numerical model of ground deformation induced by single well pumping. Comput Geotech 1998; 23(1-2): 39-60.

[2] Thangarajan M, Linn F, Uhl V, Bakaya TB, Gabaake GG. Modeling an inland delta aquifer system to evolve pre-development management schemes: a case study in upper thamalakane river valley, botswana, southern africa. Environ Geol 1999; 38(4): 285-95.

[3] McDonald MG, Harbaugh AW. The history of MODFLOW Ground Water 2003; 41(2): 280-3.

[4] Guiger N, Franz T. Visual Modflow v.2.0: Waterloo Hydrogeologic Software 1993.

[5] Gogu RC, Carabin G, Hallet V, Peters V, Dassargues A. GIS-based hydrogeological databases and groundwater modeling. Hydrogeol J 2001; 9 (6): 555-69.

[6] Jabatan Penyasiatan Kajibumi Malaysia. Krisis Air Selangor: Penyasiatan dan Pembangunan Sumber Air Tanah sebagai Sumber Air Tambahan. No. Laporan GPH 03/98.

Received: January 07, 2012

(c) Ramani Bai V; Licensee Bentham Open.

This is an open access article licensed under the terms of the Creative Commons Attribution Non-Commercial License (http://creativecommons.org/licenses/by-nc/3.0/) which permits unrestricted, non-commercial use, distribution and reproduction in any medium, provided the work is properly cited. 